\title{
Genetic correlation between composition of bovine milk fat in winter and summer, and DGAT1 and SCD1 by season interactions
}

\author{
S. Duchemin, ${ }^{1}$ H. Bovenhuis, W. M. Stoop, ${ }^{2}$ A. C. Bouwman, J. A. M. van Arendonk, and M. H. P. W. Visker \\ Animal Breeding and Genomics Centre, Wageningen University, PO Box 338, 6700 AH Wageningen, the Netherlands
}

\section{ABSTRACT}

Milk fat composition shows substantial seasonal variation, most of which is probably caused by differences in the feeding of dairy cows. The present study aimed to know whether milk fat composition in winter is genetically the same trait as milk fat composition in summer. For this purpose, we estimated heritabilities, genetic correlations, effects of acyl-coenzyme A:diacylglycerol acyltransferase 1 (DGAT1) K232A, and stearoyl-coenzyme A desaturase 1 (SCD1) A293V polymorphisms for milk fat composition in winter and summer, and tested for genotype by season interactions of DGAT1 K232A and SCD1 A293V polymorphisms. Milk samples were obtained from 2,001 first-lactation Dutch Holstein-Friesian cows, most with records in both winter and summer. Summer milk contained higher amounts of unsaturated fatty acids (FA) and lower amounts of saturated FA compared with winter milk. Heritability estimates were comparable between seasons: moderate to high for short- and medium-chain FA (0.33 to 0.74) and moderate for long-chain FA (0.19 to 0.43$)$ in both seasons. Genetic correlations between winter and summer milk were high, indicating that milk fat composition in winter and in summer can largely be considered as genetically the same trait. Effects of DGAT1 K232A and SCD1 A293V polymorphisms were similar across seasons for most FA. Allele DGAT1 $232 \mathrm{~A}$ in winter as well as in summer milk samples was negatively associated with most FA with less than 18 carbons, saturated FA, saturated FA to unsaturated $\mathrm{FA}$ ratio, and $\mathrm{C} 10$ to $\mathrm{C} 16$ unsaturation indices, and was positively associated with C14:0, unsaturated C18, unsaturated FA, and C18 and conjugated linoleic acid unsaturation indices. Allele SCD1 293V in winter as well as in summer milk samples was negatively associated with $\mathrm{C} 18: 0, \mathrm{C} 10: 1$ to cis-9 $\mathrm{C} 14: 1$, trans-11 C18:1, and $\mathrm{C} 10$ to $\mathrm{C} 14$ unsaturation indices, and positively

\footnotetext{
Received February 21, 2012.

Accepted September 14, 2012.

${ }^{1}$ Corresponding author: sandrine.duchemin@wur.nl

${ }^{2}$ Current address: Cooperative Cattle Improvement Organization
} CRV, PO Box 454, 6800 AL Arnhem, the Netherlands. associated with C8:0 to C14:0, cis-9 C16:1, and C16 to conjugated linoleic acid unsaturation indices. In addition, significant DGAT1 K232A by season interaction was found for some FA and SCD1 A293V by season interaction was only found for trans-11 C18:1. These interactions were due to scaling of genotype effects. Key words: genetic correlation, seasonal variation, DGAT1, SCD1

\section{INTRODUCTION}

Milk is an important source of lipids, proteins, vitamins, and minerals in many Western human diets. Among the milk produced by the main dairy species (e.g., cows, goats, and sheep), bovine milk is economically the most important. Bovine milk fat contains essential nutrients including fat-soluble vitamins and bioactive lipids (German and Dillard, 2006) and is pointed out by the Food and Agriculture Organization of the United Nations (FAO, 2008) as being the main source of SFA in human diets.

Genetic factors can influence milk fat composition, and its genetic variation has been reported in previous studies (e.g., Soyeurt et al., 2006; Schennink et al., 2007). Stoop et al. (2008) concluded that short- and medium-chain FA synthesized de novo are more affected by genetic factors than long-chain FA that originate from the cow's diet or from mobilization of body fat (Chilliard et al., 2000; Palmquist, 2006). Moreover, polymorphisms in diacylglycerol acyltransferase 1 $(\boldsymbol{D G A T 1})$ and stearoyl-CoA desaturase 1 (SCD1) genes have been recognized as having large effects on milk fat composition (Moioli et al., 2007; Schennink et al., 2007, 2008).

In addition, nutrition of dairy cows can considerably alter milk fat composition (e.g., Palmquist et al., 1993; Lock and Bauman, 2004; Chilliard et al., 2007). It is well established that feeding dairy cows PUFA that originate from forages results in a reduction of de novo synthesized FA and in an increase in long-chain FA in milk fat (e.g., Chilliard et al., 2001; Bauman and Griinari, 2003). Furthermore, indications exist that nutrition affects mammary lipogenic gene expression (Bernard et al., 2008; Mach et al., 2011). 
Substantial seasonal variation in milk fat composition has been found in European countries (Precht and Molketin, 2000; Thorsdottir et al., 2004; Heck et al., 2009). The main cause for this seasonal variation seems to be the differences in diets: in winter, cows in Northern Europe are usually kept inside and fed silage, whereas in summer, cows are mainly on pasture and fed fresh grass. These considerable differences in diets might affect the genetic background of milk fat composition. However, at present, no information is available of possible genotype by season interaction on milk fat composition. Therefore, our aim was to study whether winter milk fat composition is genetically the same trait as summer milk fat composition. For this purpose, we estimated heritabilities, genetic correlations, effects of DGAT1 K232A and SCD1 A293V polymorphisms for milk fat composition in winter and summer, and tested for genotype by season interactions of DGAT1 K232A and SCD1 A293V polymorphisms.

\section{MATERIALS AND METHODS}

This study is part of the Dutch Milk Genomics Initiative, which was initiated to identify opportunities to change milk composition through breeding. Based on data collected in this project, heritability estimates for milk fat composition based on winter milk samples have been published by Stoop et al. (2008) and effects of polymorphisms in the DGAT1 and SCD1 genes on milk fat composition based on winter samples have been published by Schennink et al. (2007, 2008). In the present study, heritability estimates for milk fat composition in winter and summer were obtained using a bivariate approach. Furthermore, to test whether winter milk fat composition is genetically the same trait as summer milk fat composition, we estimated genetic correlations between milk fat composition in winter and summer and, more specifically, we tested for DGAT1 and $S C D 1$ by season interactions.

\section{Animals}

Data were available on 2,001 first-lactation Holstein-Friesian cows from 398 commercial herds in the Netherlands. Winter records were available from 1,905 cows, with each cow between 63 and $282 \mathrm{~d}$ in lactation. Summer records were available from 1,795 cows, with each cow between 97 and $335 \mathrm{~d}$ in lactation. A total of 1,699 cows had both a winter and a summer record, 206 animals had only a winter milk sample, and 96 animals had only a summer sample. Details about the experimental design can be found in Stoop et al. (2008). In total, 3,700 records on milk fat composition were available.

\section{Phenotypes}

One milk sample of $500 \mathrm{~mL}$ per cow per season was collected during morning milking between February and March 2005 (winter) and between May and June 2005 (summer). Sample bottles contained sodium azide $(0.03 \% \mathrm{wt} / \mathrm{wt})$ for conservation. Fat percentage was measured by infrared spectroscopy using a MilkoScan FT6000 apparatus (Foss Electric A/S, Hillerød, Denmark) at the Milk Control Station (Qlip NV, Zutphen, the Netherlands). Milk fat composition was measured by gas chromatography at the Centraal Orgaan voor Kwaliteitsaangelegenheden in de Zuivel (COKZ) laboratory (Qlip NV, Leusden, the Netherlands), as described by Schennink et al. (2007). The FA were identified and quantified by comparing the methyl ester chromatograms of the milk fat samples with the chromatograms of pure FA methyl ester standards (Stoop et al., 2008), and were measured as weight proportion of total fat (\% wt/wt). In this study, results are shown for individual FA: C4:0 to C18:0, C10:1 to cis-9 C18:1, trans-11 C18:1, and cis-9,trans-11 C18:2 conjugated linoleic acid (CLA), cis-9,12 C18:2 and cis-9,12,15 C18:3. For $\mathrm{C} 10: 1$ and $\mathrm{C} 12: 1$, it could not be ascertained if the cis double bond occurred at the carbon 9 position. Because of co-elution associated with the gas chromatography extraction method, cis-9 C14:1 represents the sum of cis-9 $\mathrm{C} 14: 1$ and iso $\mathrm{C} 15: 0$, and cis-9 C18:1 represents the sum of cis-9 C18:1 and trans-12 C18:1. The groups of SFA, unsaturated FA (UFA), and the ratio of SFA to UFA are described in Table 1. Saturated FA and UFA sum to approximately $94 \%$ (wt/wt) of total fat.

Fatty acid unsaturation indices were defined as described by Kelsey et al. (2003):

$$
\frac{c i s-9 \text { unsaturated }}{\text { cis-9 unsaturated }+ \text { saturated }} \times 100 \text {; }
$$

for example,

$$
\mathrm{C} 14 \text { index }=\frac{\text { cis-9 C14:1 }}{\text { cis-9 } \mathrm{C} 14: 1+\mathrm{C} 14: 0} \times 100 .
$$

Indices were calculated for the following product and substrate pairs: C10:1 and C10:0 (C10index), C12:1 and C12:0 (C12index), cis-9 C14:1 and C14:0 (C14index), cis-9 C16:1 and C16:0 (C16index), cis-9 C18:1 and C18:0 (C18index), and CLA and trans-11 C18:1 (CLAindex).

\section{Genotypes}

Blood samples for DNA isolation were collected between April and June 2005. Genotyping of the DGAT1 
Table 1. Trait definition of groups of FA

\begin{tabular}{|c|c|}
\hline Group & Content \\
\hline $\mathrm{UFA}^{1}$ & $\begin{array}{l}\text { C10:1, C12:1, cis-9 C14:1, }{ }^{2} \text { cis-9 C16:1, trans- } 4-8 \text { C18:1, }{ }^{3} \text { trans-9 C18:1, trans-11 C18:1, cis-9 C18:1, }{ }^{4} \text { cis- } 11 \text { C18:1, cis-9,12 } \\
\text { C18:2, cis-9,trans-11 C18:2 (CLA), }{ }^{5} \text { and cis- } 9,12,15 \mathrm{C} 18: 3\end{array}$ \\
\hline SFA/UFA & SFA-to-unsaturated FA ratio \\
\hline \multicolumn{2}{|c|}{${ }^{1} \mathrm{UFA}=$ unsaturated FA. } \\
\hline \multicolumn{2}{|c|}{$\begin{array}{l}{ }^{2} \text { cis-9 } \mathrm{C} 14: 1 \text { due to co-elution associated with the gas chromatography (GC) extraction method represents the sum of cis-9 C14:1 and iso C15. } \\
{ }^{3} \text { trans-4-8 C18:1 due to co-elution associated with the GC extraction method represents the sum of trans-4 C18:1, trans-5 C18:1, trans-6 C18:1, } \\
\text { trans-7 C18:1, and trans-8 C18:1. }\end{array}$} \\
\hline
\end{tabular}

K232A polymorphism was performed with a TaqMan allelic discrimination assay (Applied Biosystems Inc., Foster city, CA) according to Schennink et al. (2007). For the DGAT1 K232A polymorphism, 1,692 animals were genotyped, whereas for 103 animals, no genotypes were available either because no DNA was available ( $\mathrm{n}=92$ ) or because the genotyping was ambiguous ( $\mathrm{n}$ =11). Genotypes for the SCD1 A293V polymorphism were assayed with the SNaPshot single base primer extension method (Applied Biosystems Inc.), according to Schennink et al. (2008). For the SCD1 A293V polymorphism, 1,637 animals were genotyped, whereas for 158 animals no genotypes were available either because no DNA was available $(\mathrm{n}=92)$ or the sample was genotyped ambiguously $(\mathrm{n}=66)$.

\section{Statistical Analyses}

Variance and covariance components were estimated by bivariate analyses between a trait in winter and the same trait in summer milk samples using an animal model in ASReml (Gilmour et al., 2002), as described by Stoop et al. (2008):

$$
\begin{gathered}
y_{i j k l m n}=\mu+b_{1} \times D I M_{i j k l m n}+b_{2} \times e^{-0.05 \times D I M_{i j k l m n}} \\
+b_{3} \times a f c_{i j k l m n}+b_{4} \times a f c_{i j k l m n}^{2}+\text { season }_{k}+\text { scode }_{l} \\
+\operatorname{herd}_{m}+a_{n}+e_{i j k l m n}
\end{gathered}
$$

where $y_{i j k l m n}$ is the dependent variable; $\mu$ is the overall mean; $b_{1}$ and $b_{2}$ are the regression coefficients relative to DIM $M_{i j k l m n}$; DIM $M_{i j k l m n}$ is the covariate describing the effect of DIM, modeled with a Wilmink curve (Wilmink, 1987); $b_{3}$ and $b_{4}$ are the regression coefficients relative to $a c_{i j k l m n} ; a f c_{i j k l m n}$ is the covariate describing the effect of age at first calving; season $_{k}$ is the fixed effect of calving season (June-August 2004, September-November 2004, or December 2004-February 2005); scode $_{l}$ is the fixed effect accounting for differences in genetic level between groups of proven bull daughters and young bull daughters; $h_{e r d}$ is the random effect of herd; $a_{n}$ is the random additive genetic effect of animal; and $e_{i j k l m n}$ is the random residual effect.

The variance-covariance structure of model 1 was defined as $\operatorname{Var}\left(a_{n}\right)=\mathbf{A} \sigma_{a}^{2}$, where $\mathbf{A}$ is the matrix of additive genetic relationships between individuals and $\sigma_{a}^{2}$ is the additive genetic variance; $\operatorname{Var}\left(h e r d_{m}\right)=\mathbf{I} \sigma_{\text {herd }}^{2}$, where $\mathbf{I}$ is the identity matrix and $\sigma_{\text {herd }}^{2}$ is the herd variance; and $\operatorname{Var}\left(e_{i}\right)=\mathbf{I} \sigma_{e}^{2}$, where $\mathbf{I}$ is the identity matrix and $\sigma_{e}^{2}$ is the residual variance.

Intraherd heritability was calculated (Heringstad et al., 2006) to make heritability estimates comparable with other studies that considered the effect of herd as fixed, and was defined as

$$
h^{2}=\frac{\sigma_{a}^{2}}{\sigma_{a}^{2}+\sigma_{e}^{2}} .
$$

The fraction of variance due to herd reflects the relative importance of herd effects such as feed and management practices, and was defined as

$$
\text { herd }=\frac{\sigma_{\text {herd }}^{2}}{\sigma_{a}^{2}+\sigma_{\text {herd }}^{2}+\sigma_{e}^{2}} .
$$

Phenotypic, genetic, herd, and residual correlations between a trait in winter and the same trait in summer milk samples were calculated as

$$
r=\frac{\sigma_{T w, T s}}{\sqrt{\left(\sigma_{T w}^{2} \times \sigma_{T s}^{2}\right)}},
$$

where $\sigma_{T w, T s}=$ covariance between the same trait measured in winter and summer milk samples; $\sigma_{T w}^{2}=$ variance of the trait in winter samples and $\sigma_{T s}^{2}=$ variance 
of the trait in summer samples. The genetic correlation between a trait measured in 2 different environments can be used to assess genotype by environment interaction (e.g., Falconer and Mackay, 1996). We followed this approach to assess whether milk fat composition in winter and summer milk is genetically the same trait. Significance of genetic correlations was based on the likelihood ratio test, in which the likelihood of the full model was compared with the likelihood of a model with restricted genetic correlation of 0.995 . A value of 0.995 was chosen because restricting the genetic correlation to 1 leads to singularity. Significance of the likelihood ratio test was based on a chi-squared distribution with 1 degree of freedom.

Model 1 was extended with a fixed genotype effect to estimate effects of DGAT1 (KK, KA, or AA genotypes) or $S C D 1$ (AA, AV, or VV genotypes), and to estimate $D G A T 1$ or $S C D 1$ by season interactions. Animals with missing genotypes were assigned to a separate genotype class. Missing genotypes appeared to be randomly distributed across other effects in the model.

\section{RESULTS}

\section{Milk Fat Composition in Winter and Summer}

Phenotypic means for fat composition in winter and summer milk samples are shown in Table 2. In summer milk, short-chain FA (C4:0 to C12:0) contributed $13.67 \%$ to total fat, medium-chain FA (C14:0 and C16:0) contributed $40.32 \%$, and C18:0 contributed 9.88\%. Among the unsaturated C18 FA, the largest fraction was cis-9 C18:1 (20.56\%). Fat percentage was slightly higher in winter $(4.36 \%)$ compared with summer milk $(4.26 \% ; P=2.4 \mathrm{E}-5)$. The largest differences in summer compared with winter milk were a $3.42 \%$ (wt/wt) decrease in C16:0 $(P<0.001)$, a $2.38 \%$ (wt/ wt $)$ increase in cis-9 C18:1 $(P<0.001)$ and a $1.16 \%$ (wt/wt) increase in C18:0 $(P<0.001)$. Furthermore, relatively large increases could also be seen for trans-11 C18:1 (+0.45\% wt/wt), CLA $(+0.17 \% \mathrm{wt} / \mathrm{wt})$, and cis9,12,15 C18:3 (+0.07\% wt/wt; $P<0.001)$. In addition, a $3.39 \%$ (wt/wt) decrease in SFA and a $3.00 \%$ (wt/wt) increase in UFA were observed $(P<0.001)$. Among unsaturation indices, increases for C14index $(+0.49 \%$ wt/wt) and C16index ( $+0.37 \%$ wt/wt), and a decrease in CLAindex $(2.10 \%$ wt/wt) were seen in summer compared with winter milk $(P<0.001)$. Standard deviations of unadjusted FA were, on average, $20 \%$ larger in summer than in winter milk.

\section{Heritability Estimates and Variance Components}

Heritability $\left(h^{2}\right)$, the fraction of variance due to herd (herd), and the ratios of phenotypic, genetic, and herd variances for milk fat composition in winter and summer are shown in Table 3. In winter milk, moderate to high heritability estimates were found for fat percentage, short-chain FA (C4:0 to C12:0), medium-chain FA (C14:0 and C16:0), C12:1, cis-9 C16:1, CLA, and C12 to $\mathrm{C} 18$ unsaturation indices. In summer milk, moderate to high heritability estimates were found for fat percentage, short-chain FA (C4:0 to C12:0), medium-chain FA (C14:0 and C16:0), C10:1 to cis-9 C18:1, and C10 to $\mathrm{C} 14$ unsaturation indices. In general, heritability estimates for winter and summer milk were very similar.

The fraction of variance due to herd (herd) in winter milk was moderate to high for C12:0 and most unsaturated $\mathrm{C} 18 \mathrm{FA}$. Herd in summer milk was moderate to high for C12:0, C16:0, unsaturated C18 FA, and groups of FA. In general, herd was higher in summer compared with winter milk for most FA, groups of FA, and all unsaturation indices.

Differences in $h^{2}$ and herd for milk fat composition between winter and summer can either be the result of changes in additive genetic, herd, or residual variance. Therefore, we also compared the magnitude of the individual variance components in winter and in summer milk. In summer, $\sigma_{a}^{2}$ was considerably higher for trans-11 C18:1 and CLA compared with winter milk. For most FA, $\sigma_{\text {herd }}^{2}$ was substantially higher in summer compared with winter milk, especially for trans-11 C18:1, CLA, and SFA.

\section{Correlations Between Milk Fat Composition in Winter and Summer}

The phenotypic, genetic, herd, and residual correlations between winter and summer milk fat composition are shown in Table 4. The phenotypic correlations ranged from 0.29 for trans-11 C18:1 to 0.69 for cis-9,12 C18:2 and C14index, indicating that phenotypic correlation between winter and summer milk for individual FA is in the same order of magnitude as the phenotypic correlation for fat percentage (0.63). Genetic correlations were higher than 0.90 for most FA and unsaturation indices. For C8:0 (0.93), C10:0 (0.95), C14:0 (0.94), C16:0 (0.76), trans-11 C18:1 (0.70), CLA (0.80), cis-9,12,15 C18:3 (0.79), SFA (0.77), UFA (0.82), and SFA-to-UFA ratio (0.79), genetic correlations were significantly different from $1(P<0.05)$. Herd correlations were lower than $0.42(\mathrm{C} 6: 0)$ for most FA, groups of FA and unsaturation indices, except for herd correlations of 0.54 for $\mathrm{C} 12: 0$ and 0.76 for cis-9,12 C18:2.

\section{DGAT1 Effects on Milk Fat Composition}

Estimated effects for DGAT1 K232A polymorphism on milk fat composition in winter and summer milk 
Table 2. Phenotypic mean $( \pm \mathrm{SD})$ for fat percentage, individual FA, groups of FA, and unsaturation indices based on 1,905 winter milk samples and 1,795 summer milk samples

\begin{tabular}{|c|c|c|c|}
\hline Trait & Winter $^{1}$ & Summer & $-\log (P)^{2}$ \\
\hline \multicolumn{4}{|l|}{ Milk production trait } \\
\hline Fat percentage & $4.36 \pm 0.70$ & $4.26 \pm 0.73$ & $4.6^{* * *}$ \\
\hline \multicolumn{4}{|l|}{ Individual $\mathrm{FA}^{3}$} \\
\hline C4:0 & $3.50 \pm 0.27$ & $3.52 \pm 0.35$ & $1.3^{\mathrm{NS}}$ \\
\hline C6:0 & $2.22 \pm 0.17$ & $2.17 \pm 0.21$ & $15.0^{* * *}$ \\
\hline C8:0 & $1.37 \pm 0.14$ & $1.32 \pm 0.17$ & $22.0^{* * *}$ \\
\hline C10:0 & $3.03 \pm 0.43$ & $2.87 \pm 0.46$ & $26.6^{* * *}$ \\
\hline C12:0 & $4.11 \pm 0.69$ & $3.79 \pm 0.73$ & $40.9^{* * *}$ \\
\hline C14:0 & $11.61 \pm 0.92$ & $11.15 \pm 1.06$ & $43.2^{* * *}$ \\
\hline C16:0 & $32.59 \pm 2.83$ & $29.17 \pm 3.50$ & $203.8^{* * *}$ \\
\hline C18:0 & $8.72 \pm 1.42$ & $9.88 \pm 1.77$ & $99.3^{* * *}$ \\
\hline C10:1 & $0.37 \pm 0.07$ & $0.35 \pm 0.07$ & $17.7^{* * *}$ \\
\hline $\mathrm{C} 12: 1$ & $0.12 \pm 0.03$ & $0.11 \pm 0.03$ & $23.7^{* * *}$ \\
\hline cis-9 C14:1 & $1.36 \pm 0.26$ & $1.38 \pm 0.28$ & $1.6^{*}$ \\
\hline cis-9 C16:1 & $1.45 \pm 0.32$ & $1.40 \pm 0.30$ & $6.0 * * *$ \\
\hline cis-9 C18:1 & $18.18 \pm 2.04$ & $20.56 \pm 2.80$ & $170.4^{* * *}$ \\
\hline trans-11 C18:1 & $0.78 \pm 0.22$ & $1.23 \pm 0.61$ & $174.3^{* * *}$ \\
\hline cis-9,trans-11 C18:2 (CLA) & $0.39 \pm 0.11$ & $0.56 \pm 0.28$ & $120.4^{* * *}$ \\
\hline cis-9,12 C18:2 & $1.20 \pm 0.29$ & $1.12 \pm 0.25$ & $16.7^{* * *}$ \\
\hline cis-9,12,15 C18:3 & $0.42 \pm 0.11$ & $0.49 \pm 0.16$ & $59.8^{* * *}$ \\
\hline \multicolumn{4}{|l|}{ Group of $\mathrm{FA}^{3}$} \\
\hline SFA & $69.08 \pm 2.80$ & $65.69 \pm 4.02$ & $162.1^{* * *}$ \\
\hline $\mathrm{UFA}^{4}$ & $25.03 \pm 2.42$ & $28.03 \pm 3.39$ & $158.5^{* * *}$ \\
\hline SFA/UFA & $2.79 \pm 0.37$ & $2.39 \pm 0.43$ & $159.7^{* * *}$ \\
\hline \multicolumn{4}{|l|}{ Unsaturation index ${ }^{5}$} \\
\hline C10 index & $10.89 \pm 1.91$ & $11.00 \pm 1.82$ & $1.1^{\mathrm{NS}}$ \\
\hline C12 index & $2.74 \pm 0.54$ & $2.76 \pm 0.56$ & $0.6^{\mathrm{NS}}$ \\
\hline C14 index & $10.51 \pm 1.84$ & $11.00 \pm 1.84$ & $15.1^{* * *}$ \\
\hline C16 index & $4.24 \pm 0.82$ & $4.61 \pm 0.92$ & $36.4^{* * *}$ \\
\hline C18 index & $67.62 \pm 3.74$ & $67.60 \pm 3.89$ & $0.1^{\mathrm{NS}}$ \\
\hline CLA index & $33.72 \pm 4.06$ & $31.62 \pm 3.96$ & $57.0^{* * *}$ \\
\hline
\end{tabular}

${ }^{1}$ Data based on winter milk samples for fat percentage, C4:0 to C18:0, cis-9 C18:1, trans-11 C18:1, cis9,trans-11 C18:2 conjugated linoleic acid (CLA), cis-9,12 C18:2, cis-9,12,15 C18:3, and SFA-to-UFA ratio have been published by Stoop et al. (2008).

${ }^{2}$ Significance levels were assessed by a $t$-test considering winter and summer milk samples as independent traits, and $-\log (P)$ represent the $-\log (P$-value $)$ of the difference between seasons.

${ }^{3}$ Expressed in \% wt/wt.

${ }^{4} \mathrm{UFA}=$ unsaturated FA.

${ }^{5}$ Unsaturation indices calculated as unsaturated/(unsaturated + saturated) $\times 100$.

${ }^{* * *} P<0.001 ; * P \leq 0.05$.

samples are shown in Table 5. The 232A allele was associated with lower fat percentage in both winter and summer milk. In winter as well as in summer milk, the $232 \mathrm{~A}$ allele was negatively associated with most FA with less than 18 carbons, SFA, SFA-to-UFA ratio, and $\mathrm{C} 10$ to $\mathrm{C} 16$ unsaturation indices, and was positively associated with $\mathrm{C} 14: 0$, unsaturated $\mathrm{C} 18$, UFA, and $\mathrm{C} 18$ and CLA unsaturation indices. In general, effects of DGAT1 K232A polymorphism were very similar in winter and in summer milk.

Significant DGAT1 by season interaction was found for C4:0 to C14:0, cis-9 C16:1, cis-9 C18:1, CLA, cis9,12,15 C18:3, SFA, UFA, and C14 and C16 unsaturation indices $(P \leq 0.05)$. Significant $D G A T 1$ by season interactions seem to be due to scaling rather than reranking: genotype effects in both seasons were in the same direction but of a different magnitude. Figure 1 shows an example of scaling of the genotype effects on cis-9 C18:1.

\section{SCD1 Effects on Milk Fat Composition}

Estimated effects for SCD1 A293V polymorphism on milk fat composition in winter and summer milk samples are shown in Table 6 . The $S C D 1$ A293V polymorphism had no significant effects on fat percentage in winter as well as in summer milk. In winter milk, the $293 \mathrm{~V}$ allele was negatively associated with C18:0, C10:1 to cis-9 C14:1, trans-11 C18:1, cis-9,12,15 C18:3, and $\mathrm{C} 10$ to $\mathrm{C} 14$ unsaturation indices, and positively associated with C8:0 to C14:0, cis-9 C16:1, CLA, and C16 to CLA unsaturation indices. In summer milk, the $293 \mathrm{~V}$ allele was negatively associated with C18:0, C10:1 to cis-9 C14:1, trans-11 C18:1, CLA, and C10 
Table 3. Heritability $\left[h^{2} ; h^{2}=\sigma_{a}^{2} /\left(\sigma_{a}^{2}+\sigma_{e}^{2}\right)\right]$, fraction of variance due to herd $\left[\right.$ herd; herd $\left.=\sigma_{\text {herd }}^{2} /\left(\sigma_{a}^{2}+\sigma_{\text {herd }}^{2}+\sigma_{e}^{2}\right)\right]$, phenotypic $\left(\sigma_{p}^{2} ; \sigma_{p}^{2}=\sigma_{a}^{2}+\sigma_{\text {herd }}^{2}+\sigma_{e}^{2}\right)$, genetic $\left(\sigma_{a}^{2}\right)$, and herd $\left(\sigma_{\text {herd }}^{2}\right)$ variances and ratios of $\left(\sigma_{p}^{2}\right),\left(\sigma_{a}^{2}\right)$, and $\left(\sigma_{\text {herd }}^{2}\right)$ for fat percentage, individual FA, groups of FA, and unsaturation indices based on 1,905 winter milk samples and 1,795 summer milk samples

\begin{tabular}{|c|c|c|c|c|c|c|c|c|c|c|}
\hline Trait & $h^{2}$ winter $^{1}$ & $h^{2}$ summer $^{1}$ & $\begin{array}{c}\text { herd } \\
\text { winter }^{2}\end{array}$ & $\begin{array}{c}\text { herd } \\
\text { summer }^{2}\end{array}$ & $\sigma_{p}^{2}$ summer $^{3}$ & $\sigma_{a}^{2}$ summer & $\sigma_{\text {herd }}^{2}$ summer & $\begin{array}{c}\sigma_{p}^{2} \text { summer/ } \\
\sigma_{p}^{2} \text { winter }^{3}\end{array}$ & $\begin{array}{c}\sigma_{a}^{2} \text { summer/ } \\
\sigma_{a}^{2} \text { winter }\end{array}$ & $\begin{array}{c}\sigma_{\text {herd }}^{2} \text { summer } / \\
\sigma_{\text {herd }}^{2} \text { winter }\end{array}$ \\
\hline \multicolumn{11}{|l|}{ Milk production trait } \\
\hline Fat percentage & 0.57 & 0.63 & 0.06 & 0.11 & 0.58 & 0.33 & 0.06 & 1.12 & 1.16 & 1.92 \\
\hline \multicolumn{11}{|l|}{ Individual FA } \\
\hline C4:0 & 0.43 & 0.38 & 0.16 & 0.24 & 0.13 & 0.04 & 0.03 & 1.63 & 1.29 & 2.39 \\
\hline $\mathrm{C} 6: 0$ & 0.48 & 0.41 & 0.16 & 0.18 & 0.04 & 0.01 & 0.01 & 1.56 & 1.29 & 1.80 \\
\hline C8:0 & 0.62 & 0.41 & 0.20 & 0.19 & 0.03 & 0.01 & 0.01 & 1.42 & 0.96 & 1.35 \\
\hline C10:0 & 0.74 & 0.55 & 0.23 & 0.19 & 0.22 & 0.10 & 0.04 & 1.11 & 0.88 & 0.90 \\
\hline $\mathrm{C} 12: 0$ & 0.64 & 0.51 & 0.43 & 0.40 & 0.55 & 0.17 & 0.22 & 1.10 & 1.16 & 1.92 \\
\hline C14:0 & 0.58 & 0.51 & 0.17 & 0.34 & 1.15 & 0.39 & 0.39 & 1.29 & 0.90 & 2.55 \\
\hline $\mathrm{C} 16: 0$ & 0.37 & 0.36 & 0.30 & 0.51 & 12.40 & 2.23 & 6.28 & 1.51 & 1.06 & 2.58 \\
\hline $\mathrm{C} 18: 0$ & 0.24 & 0.19 & 0.19 & 0.30 & 3.15 & 0.41 & 0.95 & 1.59 & 1.07 & 2.56 \\
\hline $\mathrm{C} 10: 1$ & 0.33 & 0.47 & 0.10 & 0.25 & $5.11 \mathrm{E}-3$ & $1.80 \mathrm{E}-3$ & $1.29 \mathrm{E}-3$ & 1.15 & 1.36 & 2.87 \\
\hline $\mathrm{C} 12: 1$ & 0.37 & 0.48 & 0.21 & 0.30 & $0.95 \mathrm{E}-3$ & $0.32 \mathrm{E}-3$ & $0.29 \mathrm{E}-3$ & 1.21 & 1.39 & 1.77 \\
\hline cis-9 C14:1 & 0.33 & 0.46 & 0.07 & 0.15 & 0.08 & 0.03 & 0.01 & 1.23 & 1.54 & 2.72 \\
\hline cis-9 C16:1 & 0.42 & 0.39 & 0.07 & 0.09 & 0.09 & 0.03 & 0.01 & 0.90 & 0.80 & 1.29 \\
\hline cis-9 C18:1 & 0.27 & 0.37 & 0.29 & 0.35 & 7.79 & 1.88 & 2.69 & 1.86 & 2.30 & 2.26 \\
\hline trans-11 C18:1 & 0.29 & 0.20 & 0.58 & 0.64 & 0.38 & 0.03 & 0.25 & 8.28 & 4.91 & 9.10 \\
\hline cis-9,trans-11 C18:2 (CLA) ${ }^{3}$ & 0.43 & 0.28 & 0.51 & 0.58 & 0.08 & 0.01 & 0.05 & 6.09 & 3.32 & 7.02 \\
\hline cis-9,12 C18:2 & 0.20 & 0.23 & 0.50 & 0.57 & 0.07 & 0.01 & 0.04 & 0.82 & 0.84 & 0.93 \\
\hline cis- $9,12,15$ C18:3 & 0.26 & 0.22 & 0.64 & 0.63 & $25.94 \mathrm{E}-3$ & $2.15 \mathrm{E}-3$ & $16.30 \mathrm{E}-3$ & 2.19 & 1.96 & 2.14 \\
\hline \multicolumn{11}{|l|}{ Group of FA } \\
\hline SFA & 0.30 & 0.34 & 0.29 & 0.44 & 15.88 & 3.06 & 6.94 & 2.00 & 1.83 & 3.02 \\
\hline $\mathrm{UFA}^{4}$ & 0.30 & 0.32 & 0.29 & 0.40 & 11.34 & 2.20 & 4.55 & 1.93 & 1.78 & 2.66 \\
\hline \multirow{2}{*}{\multicolumn{11}{|c|}{ Unsaturation index }} \\
\hline & & & & & & & & & & \\
\hline C10 index & 0.31 & 0.43 & 0.06 & 0.13 & 3.29 & 1.22 & 0.44 & 0.94 & 1.21 & 1.98 \\
\hline C12 index & 0.36 & 0.51 & 0.06 & 0.15 & 0.31 & 0.14 & 0.05 & 1.12 & 1.44 & 2.82 \\
\hline C14 index & 0.44 & 0.52 & 0.06 & 0.07 & 3.36 & 1.64 & 0.22 & 1.05 & 1.25 & 1.08 \\
\hline C16 index & 0.48 & 0.33 & 0.06 & 0.13 & 0.89 & 0.26 & 0.12 & 1.28 & 0.83 & 2.68 \\
\hline C18 index & 0.35 & 0.31 & 0.06 & 0.11 & 15.38 & 4.18 & 1.72 & 1.09 & 0.89 & 2.17 \\
\hline CLA index & 0.26 & 0.25 & 0.08 & 0.17 & 16.03 & 3.39 & 2.69 & 0.96 & 0.85 & 2.00 \\
\hline \multicolumn{11}{|c|}{${ }^{1}$ Standard errors between 0.01 and 0.12 . } \\
\hline \multicolumn{11}{|c|}{${ }^{2}$ Standard errors between 0.02 and 0.08 . } \\
\hline \multicolumn{11}{|c|}{${ }^{3} \mathrm{CLA}=$ conjugated linoleic acid. } \\
\hline${ }^{4} \mathrm{UFA}=$ unsaturated FA. & & & & & & & & & & \\
\hline
\end{tabular}


Table 4. Phenotypic $\left(r_{p}\right)$, genetic $\left(r_{a}\right)$, herd $\left(r_{h e r d}\right)$, and residual $\left(r_{e}\right)$ correlations (SE in parentheses) for fat percentage, individual FA, groups of FA, and unsaturation indices between 1,905 winter milk samples and 1,795 summer milk samples

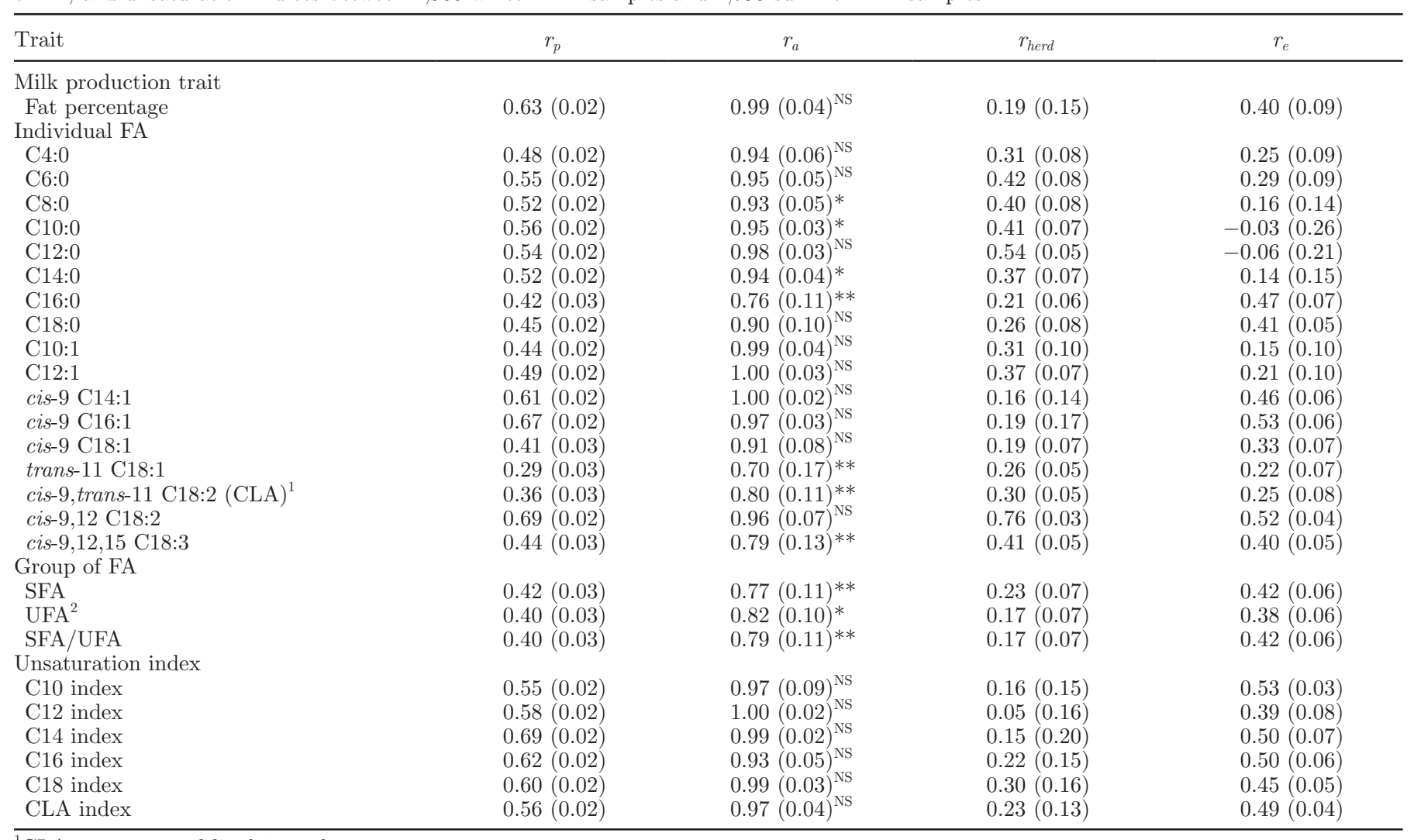

${ }^{1} \mathrm{CLA}=$ conjugated linoleic acid.

${ }^{2} \mathrm{UFA}=$ unsaturated FA.

${ }^{* *} P<0.01 ;{ }^{*} P \leq 0.05$ (indicate whether the genetic correlation differs significantly from 0.995 ).

to C14 unsaturation indices, and positively associated with C8:0 to C14:0, cis-9 C16:1, cis-9,12,15 C18:3, and C16 to CLA unsaturation indices. In general, effects of $S C D 1 \mathrm{~A} 293 \mathrm{~V}$ polymorphism were very similar in winter and in summer milk.

Significant $S C D 1$ by season interaction was found only for trans-11 C18:1 $(P=0.03)$. The $293 \mathrm{~V}$ allele was negatively associated with trans-11 C18:1 and this negative effect was larger in summer than in winter milk (Figure 2).

\section{DISCUSSION}

Heritability estimates for fat composition in winter and summer milk were very similar, and estimates of winter milk are comparable with results published by Stoop et al. (2008), which were based on univariate analyses. Intraherd heritability estimates in our study are higher than estimates reported by others (Renner and Kosmack, 1974; Karijord et al., 1982; Soyeurt et al., 2008). This might be because these studies used different methods to measure FA, or studied different breeds.
Genetic correlations between winter and summer milk were high for all FA, indicating that milk fat composition in winter and in summer can be largely considered as genetically the same trait. Effects of DGAT1 K232A and SCD1 A293V polymorphisms on milk fat composition in winter and in summer were similar and their effects in summer milk confirm the results of Schennink et al. $(2007,2008)$ for winter milk. The results also showed several differences between winter and summer milk, which will be discussed in more detail.

\section{Effects of Season on Milk Fat Composition}

Summer milk contained larger proportions of C18:0 and unsaturated $\mathrm{C} 18$, and smaller proportions of shortand medium-chain FA compared with winter milk, which is in agreement with proportions reported in the literature (Palmquist et al., 1993; Soyeurt et al., 2008; Heck et al., 2009). Differences between winter and summer milk fat in our study could be partly due to differences in lactation stage, as cows in summer were, on average, $80 \mathrm{~d}$ later in lactation than in winter (247 vs. 
Table 5. Effects of the diacylglycerol acyltransferase 1 (DGAT1) K232A polymorphism (SE in parentheses) on fat percentage, individual FA, groups of FA, and unsaturation indices based on 1,905 winter milk samples and 1,795 summer milk samples

\begin{tabular}{|c|c|c|c|c|c|c|c|}
\hline \multirow[b]{2}{*}{ Trait } & \multirow{2}{*}{$\begin{array}{c}-\log (P) D G A T 1 \times \\
\text { season interaction }\end{array}$} & \multicolumn{3}{|c|}{ Winter } & \multicolumn{3}{|c|}{ Summer } \\
\hline & & $\mathrm{KA}^{2}(\mathrm{n}=829)$ & $\mathrm{AA}^{3}(\mathrm{n}=644)$ & $-\log (P)^{4}$ & $\mathrm{KA}^{2}(\mathrm{n}=773)$ & $\mathrm{AA}^{3}(\mathrm{n}=592)$ & $-\log (P)^{4}$ \\
\hline \multicolumn{8}{|l|}{ Milk production trait } \\
\hline Fat percentage & $1.2^{\mathrm{NS}}$ & $-0.46(0.04)$ & $-0.99(0.04)$ & $126.9^{* * *}$ & $-0.46(0.04)$ & $-0.95(0.05)$ & $126.8^{* * *}$ \\
\hline \multicolumn{8}{|l|}{ Individual FA } \\
\hline $\mathrm{C} 4: 0$ & $1.5^{*}$ & $-0.01(0.02)$ & $0.01(0.02)$ & $0.3^{\mathrm{NS}}$ & $0.01(0.02)$ & $0.00(0.02)$ & $0.2^{\mathrm{NS}}$ \\
\hline C6:0 & $5.1^{* * *}$ & $-0.02(0.01)$ & $-0.06(0.01)$ & $13.4^{* * *}$ & $-0.04(0.01)$ & $-0.12(0.01)$ & $14.1^{* * *}$ \\
\hline C8:0 & $5.0^{* * *}$ & $0.00(0.01)$ & $-0.03(0.01)$ & $9.2^{* * *}$ & $-0.02(0.01)$ & $-0.08(0.01)$ & $10.0^{* * *}$ \\
\hline C10:0 & $5.1^{* * *}$ & $0.07(0.03)$ & $0.02(0.03)$ & $3.2^{* * *}$ & $-0.03(0.03)$ & $-0.14(0.03)$ & $3.7^{* * *}$ \\
\hline $\mathrm{C} 12: 0$ & $2.7^{* *}$ & $0.13(0.04)$ & $0.10(0.04)$ & $1.0^{\mathrm{NS}}$ & $-0.01(0.04)$ & $-0.07(0.04)$ & $1.0^{\mathrm{NS}}$ \\
\hline C14:0 & $4.0^{* * *}$ & $0.44(0.06)$ & $0.80(0.06)$ & $33.4^{* * *}$ & $0.30(0.07)$ & $0.52(0.07)$ & $32.6^{* * *}$ \\
\hline C16:0 & $0.1^{\mathrm{NS}}$ & $-1.05(0.16)$ & $-2.56(0.17)$ & $65.0^{* * *}$ & $-1.14(0.17)$ & $-2.63(0.18)$ & $65.6^{* * *}$ \\
\hline $\mathrm{C} 18: 0$ & $0.0^{\mathrm{NS}}$ & $-0.16(0.09)$ & $-0.07(0.10)$ & $0.7^{\mathrm{NS}}$ & $-0.16(0.11)$ & $-0.11(0.12)$ & $0.7^{\mathrm{NS}}$ \\
\hline C10:1 & $0.7^{\mathrm{NS}}$ & $0.00(0.00)$ & $-0.02(0.00)$ & $8.4^{* * *}$ & $-0.01(0.00)$ & $-0.03(0.00)$ & $8.9^{* * *}$ \\
\hline $\mathrm{C} 12: 1$ & $1.0^{\mathrm{NS}}$ & $0.23 \mathrm{E}-3(1.76 \mathrm{E}-3)$ & $-4.88 \mathrm{E}-3(1.89 \mathrm{E}-3)$ & $3.0^{* * *}$ & $-3.85 \mathrm{E}-3(1.82 \mathrm{E}-3)$ & $-6.59 \mathrm{E}-3(1.97 \mathrm{E}-3)$ & $3.0^{* * *}$ \\
\hline cis-9 C14:1 & $0.3^{\mathrm{NS}}$ & $-0.01(0.02)$ & $-0.04(0.02)$ & $1.3^{*}$ & $-0.03(0.02)$ & $-0.04(0.02)$ & $1.3^{*}$ \\
\hline cis-9 C16:1 & $1.9^{*}$ & $-0.14(0.02)$ & $-0.32(0.02)$ & $53.2^{* * *}$ & $-0.12(0.02)$ & $-0.27(0.02)$ & $53.7^{* * *}$ \\
\hline cis-9 C18:1 & $2.6^{* *}$ & $0.66(0.12)$ & $1.73(0.13)$ & $61.0^{* * *}$ & $1.01(0.15)$ & $2.34(0.16)$ & $62.8^{* * *}$ \\
\hline trans-11 C18:1 & $0.4^{\mathrm{NS}}$ & $-0.01(0.01)$ & $0.03(0.01)$ & $3.5^{* * *}$ & $0.02(0.03)$ & $0.05(0.03)$ & $3.9^{* * *}$ \\
\hline cis-9,trans-11 C18:2 (CLA) ${ }^{5}$ & $2.3^{* *}$ & $0.02(0.01)$ & $0.05(0.01)$ & $16.0^{* * *}$ & $0.04(0.01)$ & $0.09(0.01)$ & $15.2^{* * *}$ \\
\hline cis-9,12 C18:2 & $0.4^{\mathrm{NS}}$ & $0.06(0.01)$ & $0.13(0.02)$ & $28.2^{* * *}$ & $0.07(0.01)$ & $0.15(0.01)$ & $29.0^{* * *}$ \\
\hline cis-9,12,15 C18:3 & $1.3^{*}$ & $0.01(0.00)$ & $0.04(0.01)$ & $23.5^{* * *}$ & $0.01(0.01)$ & $0.06(0.01)$ & $22.8^{* * *}$ \\
\hline \multicolumn{8}{|l|}{ Group of FA } \\
\hline SFA & $2.8^{* *}$ & $-0.72(0.17)$ & $-2.00(0.18)$ & $44.3^{* * *}$ & $-1.20(0.21)$ & $-2.84(0.22)$ & $46.6^{* * *}$ \\
\hline $\mathrm{UFA}^{6}$ & $3.0^{* *}$ & $0.62(0.14)$ & $1.68(0.15)$ & $42.4^{* * *}$ & $1.04(0.18)$ & $2.43(0.19)$ & $44.7^{* * *}$ \\
\hline SFA/UFA & $0.4^{\mathrm{NS}}$ & $-0.11(0.02)$ & $-0.26(0.02)$ & $44.8^{* * *}$ & $-0.14(0.02)$ & $-0.30(0.02)$ & $46.2^{* * *}$ \\
\hline \multicolumn{8}{|l|}{ Unsaturation index } \\
\hline C10 index & $1.1^{\mathrm{NS}}$ & $-0.31(0.12)$ & $-0.55(0.13)$ & $2.3^{* *}$ & $-0.20(0.12)$ & $-0.26(0.13)$ & $2.0^{* *}$ \\
\hline C12 index & $1.1^{\mathrm{NS}}$ & $-0.09(0.03)$ & $-0.20(0.04)$ & $5.5^{* * *}$ & $-0.09(0.04)$ & $-0.13(0.04)$ & $5.3^{* * *}$ \\
\hline C14 index & $1.4^{*}$ & $-0.49(0.11)$ & $-0.98(0.12)$ & $12.8^{* * *}$ & $-0.47(0.12)$ & $-0.75(0.13)$ & $12.6^{* * *}$ \\
\hline C16 index & $1.8^{*}$ & $-0.26(0.05)$ & $-0.58(0.06)$ & $21.2^{* * *}$ & $-0.20(0.06)$ & $-0.41(0.07)$ & $21.7^{* * *}$ \\
\hline C18 index & $0.6^{\mathrm{NS}}$ & $1.18(0.24)$ & $2.23(0.26)$ & $23.5^{* * *}$ & $1.40(0.25)$ & $2.71(0.27)$ & $23.3^{* * *}$ \\
\hline CLA index & $0.7^{\mathrm{NS}}$ & $1.09(0.27)$ & $1.82(0.29)$ & $15.0^{* * *}$ & $1.27(0.26)$ & $2.36(0.28)$ & $15.3^{* * *}$ \\
\hline
\end{tabular}

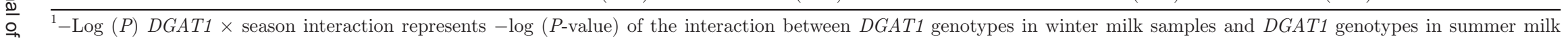

$\stackrel{\text { O }}{P}$ - Log $(P)$

兽. $\quad{ }^{2}$ Estimated contrast of KA - KK genotypes, where KK is set to zero, obtained using model 1 extended with DGAT1 K232A as a fixed genotype effect.

ஸ ${ }^{3}$ Estimated contrast of AA - KK genotypes, where KK is set to zero, obtained using model 1 extended with DGAT1 K232A as a fixed genotype effect.

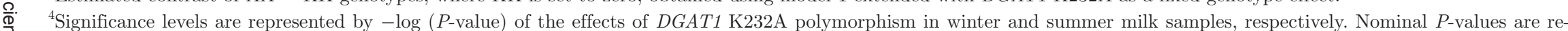
ported.

$\lesssim \quad{ }^{5} \mathrm{CLA}=$ conjugated linoleic acid.

을 $\quad{ }^{6} \mathrm{UFA}=$ unsaturated $\mathrm{FA}$

○ $\quad * * * P<0.001 ;{ }^{* *} P<0.01 ;{ }^{*} P \leq 0.05$. 
600

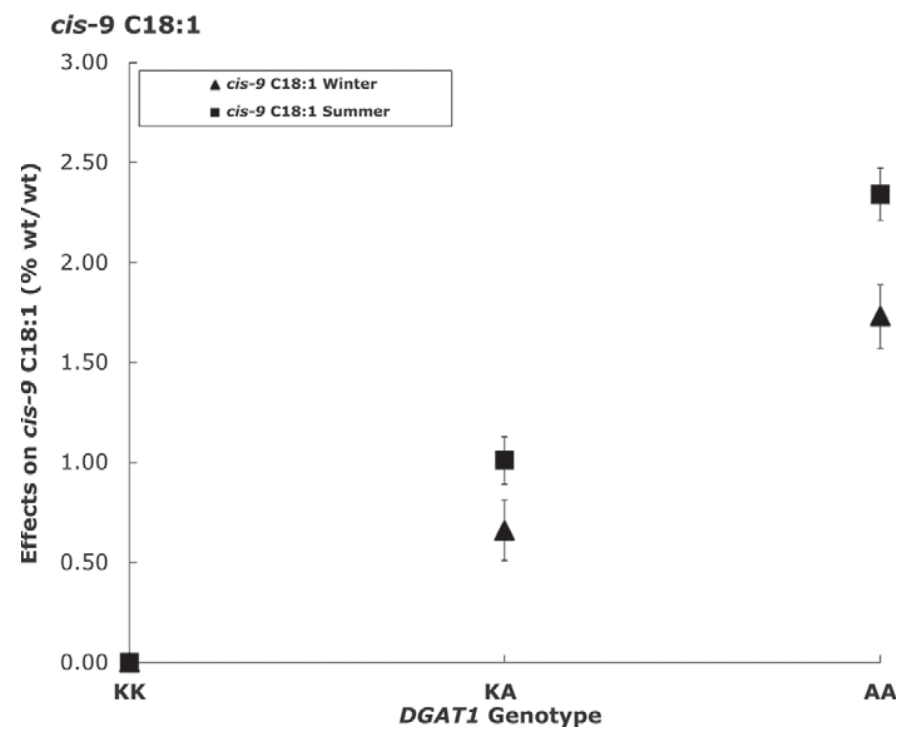

Figure 1. Estimated effects of diacylglycerol acyltransferase 1 (DGAT1) K232A polymorphism in winter and summer samples represented by the contrasts of AA - KK and KA - KK genotypes, where $\mathrm{KK}$ is set to zero. These contrasts illustrate the significant DGAT1 K232A by season interaction on cis-9 C18:1. Standard errors are shown as error bars.

$167 \mathrm{~d})$. Effects of lactation stage were accounted for in the statistical analysis and are known to be relatively small (Kelsey et al., 2003; Stoop et al., 2008). Therefore, we expect that it has not influenced our results.

Seasonal variation in milk fat composition seems to be the result of pasture grazing of dairy cows in summer compared with winter (Precht and Molketin, 2000; Thorsdottir et al., 2004). Grazing or availability of fresh-cut grass in summer will result in a different dietary supply of FA, because fresh-cut grass contains more PUFA than conserved forages, which are affected by decreases in the leaf:stem ratio during the maturation period (Dewhurst et al., 2001). It is well known that a supply of PUFA through the diet of dairy cows decreases de novo synthesized FA and increases longchain FA in milk fat (e.g., Chilliard et al., 2001; Agenäs et al., 2002; Bernard et al., 2008). Therefore, our observation that summer milk had higher amounts of longchain FA and lower amounts of de novo synthesized FA compared with winter milk is probably because about $50 \%$ of the cows in our experiment had access to pasture in summer (3.5 to $24 \mathrm{~h} / \mathrm{d}$ ), whereas all cows were kept indoors in winter.

Differences in dietary supply of FA between winter and summer were also reflected by our relatively low herd correlations between milk fat composition in winter and summer milk. This suggests that the effect of herd, of which diet is a part, on milk fat composition is not constant over the year. This might be related to the considerably higher herd variances in summer compared with winter milk found in our results. Variation due to herd might be due to several factors; however, differences in feeding regimens between and within herds play a major role. Larger herd variances in summer are most likely due to larger differences in feeding strategies between herds as well as within a herd: apparently the quantity and composition of forages, either fresh or conserved, varies more between herds and within a herd in summer compared with winter.

In contrast, herd correlations found in our study for $\mathrm{C} 12: 0$ and for cis-9,12 C18:2 were higher than for other FA, probably because the supply of these FA in a herd was relatively constant during the year. Most concentrate feeds supplied to Dutch dairy cows have high concentrations of $\mathrm{C} 12: 0$, due to the presence of ingredients such as palm kernel expeller (47\%) and extracted coconut (48\%), both rich in C12:0 (Grummer, 1991; Heck et al., 2009). The high herd correlation for C12:0 might be because in a herd, the same type of concentrate is fed to cows in both winter and summer. cis-9,12 C18:2 is one of the major PUFA found in maize silage (Chilliard et al., 2001; Khanal et al., 2008). The high herd correlation for this FA suggests that herds that feed on maize silage do this in winter as well as in summer.

It is well established that the supply of FA reaching the mammary gland of a cow for milk fat synthesis can be indirectly affected by processes that occur in the rumen known to convert PUFA into SFA (e.g., Chilliard et al., 2001; Jenkins et al., 2008). These processes are dependent on many factors, which include quantity and composition of microbiota (Harfoot and Hazlewood, 1997; Lock and Bauman, 2004), the proportion of forages and concentrates in the cow's diet (Dewhurst et al., 2006), and the source of the PUFA supplied to dairy cows (Sterk, 2011). Therefore, part of the observed differences in milk fat composition between winter and summer milk can also be attributed to dietary effects on processes in the rumen, which are known to affect the amounts of trans-11 C18:1 and CLA reaching the mammary gland of a cow (Mach et al., 2011).

\section{Effects of Polymorphisms in DGAT1 and in SCD1}

Some studies indicate that nutrition affects mammary expression of lipogenic genes (Bernard et al., 2008; Mach et al., 2011). Therefore, effects of polymorphisms in DGAT1 and SCD1 on milk fat composition might differ between winter and summer. In the present study, significant DGAT1 by season interactions were found on many FA, and a $S C D 1$ by season interaction effect was found only on trans-11 C18:1. However, estimated genotype effects suggest that these interactions 
Table 6. Effects of the stearoyl-CoA desaturase 1 (SCD1) A293V polymorphism (SE in parentheses) on fat percentage, individual FA, groups of FA, and unsaturation indices based on 1,905 winter milk samples and 1,795 summer milk samples

\begin{tabular}{|c|c|c|c|c|c|c|c|}
\hline \multirow[b]{2}{*}{ Trait } & \multirow{2}{*}{$\begin{array}{l}-\log (P) S C D 1 \times \\
\text { season interaction }\end{array}$} & \multicolumn{3}{|c|}{ Winter } & \multicolumn{3}{|c|}{ Summer } \\
\hline & & $\mathrm{VA}^{2}(\mathrm{n}=689)$ & $\mathrm{VV}^{3}(\mathrm{n}=117)$ & $-\log (P)^{4}$ & $\mathrm{VA}^{2}(\mathrm{n}=653)$ & $\mathrm{VV}^{3}(\mathrm{n}=103)$ & $-\log (P)^{4}$ \\
\hline \multicolumn{8}{|l|}{ Milk production trait } \\
\hline Fat percentage & $0.7^{\mathrm{NS}}$ & $0.00(0.03)$ & $0.05(0.07)$ & $0.1^{\mathrm{NS}}$ & $-0.02(0.04)$ & $0.04(0.07)$ & $0.1^{\mathrm{NS}}$ \\
\hline \multicolumn{8}{|l|}{ Individual FA } \\
\hline $\mathrm{C} 4: 0$ & $0.5^{\mathrm{NS}}$ & $-0.02(0.01)$ & $0.01(0.03)$ & $1.1_{\mathrm{NS}}^{\mathrm{NS}}$ & $-0.01(0.02)$ & $0.05(0.03)$ & $1.1_{\mathrm{NS}}^{\mathrm{NS}}$ \\
\hline C6:0 & $0.7^{\mathrm{NS}}$ & $0.01(0.01)$ & $0.02(0.02)$ & $1.0^{\mathrm{NS}}$ & $0.01(0.01)$ & $0.06(0.02)$ & $0.7^{\mathrm{NS}}$ \\
\hline $\mathrm{C} 8: 0$ & $0.8^{\mathrm{NS}}$ & $0.01(0.01)$ & $0.02(0.01)$ & $1.7^{*}$ & $0.02(0.01)$ & $0.05(0.02)$ & $1.5^{*}$ \\
\hline C10:0 & $0.3^{\mathrm{NS}}$ & $0.10(0.02)$ & $0.15(0.04)$ & $8.1^{* * *}$ & $0.09(0.02)$ & $0.20(0.04)$ & $7.5^{* * *}$ \\
\hline C12:0 & $0.1^{\mathrm{NS}}$ & $0.09(0.03)$ & $0.14(0.06)$ & $2.3^{* *}$ & $0.05(0.03)$ & $0.13(0.06)$ & $2.3^{* *}$ \\
\hline C14:0 & $0.9^{\mathrm{NS}}$ & $0.22(0.04)$ & $0.40(0.09)$ & $6.5^{* * *}$ & $0.13(0.05)$ & $0.30(0.09)$ & $6.5^{* * *}$ \\
\hline C16:0 & $0.6^{\mathrm{NS}}$ & $-0.14(0.13)$ & $-0.26(0.25)$ & $0.4^{\mathrm{NS}}$ & $-0.12(0.13)$ & $0.22(0.27)$ & $0.3^{\mathrm{NS}}$ \\
\hline C18:0 & $0.3^{\mathrm{NS}}$ & $-0.29(0.07)$ & $-0.43(0.13)$ & $5.5^{* * *}$ & $-0.24(0.08)$ & $-0.64(0.16)$ & $6.0^{* * *}$ \\
\hline C10:1 & $0.5^{\mathrm{NS}}$ & $-0.03(0.00)$ & $-0.06(0.01)$ & $42.7^{* * *}$ & $-0.03(0.00)$ & $-0.05(0.01)$ & $42.9^{* * *}$ \\
\hline $\mathrm{C} 12: 1$ & $0.0^{\mathrm{NS}}$ & $-0.01(0.00)$ & $-0.02(0.00)$ & $25.0^{* * *}$ & $-0.01(0.00)$ & $-0.02(0.00)$ & $24.1 * * *$ \\
\hline cis-9 C14:1 & $0.0^{\mathrm{NS}}$ & $-0.17(0.01)$ & $-0.32(0.02)$ & $78.8^{* * *}$ & $-0.17(0.01)$ & $-0.33(0.02)$ & $77.7^{* * *}$ \\
\hline cis-9 C16:1 & $0.2^{\mathrm{NS}}$ & $0.16(0.02)$ & $0.34(0.03)$ & $47.6^{* * *}$ & $0.15(0.01)$ & $0.35(0.03)$ & $48.4^{* * *}$ \\
\hline cis-9 C18:1 & $0.5^{\mathrm{NS}}$ & $0.09(0.09)$ & $0.20(0.18)$ & $0.3^{\mathrm{NS}}$ & $0.17(0.12)$ & $-0.04(0.24)$ & $0.4^{\mathrm{NS}}$ \\
\hline trans-11 C18:1 & $1.6^{*}$ & $-0.01(0.01)$ & $-0.04(0.02)$ & $2.1^{* *}$ & $-0.07(0.02)$ & $-0.11(0.04)$ & $2.3^{* *}$ \\
\hline cis-9,trans-11 C18:2 (CLA $)^{5}$ & $0.4^{\mathrm{NS}}$ & $0.02(0.00)$ & $0.02(0.01)$ & $2.5^{* *}$ & $-0.07(0.02)$ & $-0.11(0.04)$ & $1.7^{*}$ \\
\hline cis-9,12 C18:2 & $0.4^{\mathrm{NS}}$ & $0.01(0.01)$ & $-0.02(0.02)$ & $0.9^{\mathrm{NS}}$ & $0.01(0.01)$ & $-0.04(0.02)$ & $1.4^{*}$ \\
\hline cis-9,12,15 C18:3 & $1.1^{\mathrm{NS}}$ & $0.01(0.00)$ & $-0.01(0.01)$ & $1.5^{*}$ & $0.02(0.01)$ & $0.00(0.01)$ & $2.2^{* *}$ \\
\hline \multicolumn{8}{|l|}{ Group of FA } \\
\hline SFA & $0.2^{\mathrm{NS}}$ & $-0.02(0.13)$ & $0.05(0.25)$ & $0.0^{\mathrm{NS}}$ & $-0.06(0.16)$ & $0.29(0.32)$ & $0.0^{\mathrm{NS}}$ \\
\hline $\mathrm{UFA}^{6}$ & $0.5^{\mathrm{NS}}$ & $0.04(0.11)$ & $0.08(0.22)$ & $0.0^{\mathrm{NS}}$ & $0.07(0.14)$ & $-0.21(0.28)$ & $0.1^{\mathrm{NS}}$ \\
\hline SFA/UFA & $0.3^{\mathrm{NS}}$ & $-0.01(0.02)$ & $-0.01(0.03)$ & $0.0^{\mathrm{NS}}$ & $0.00(0.02)$ & $0.03(0.03)$ & $0.0^{\mathrm{NS}}$ \\
\hline \multicolumn{8}{|l|}{ Unsaturation index } \\
\hline C10 index & $0.1^{\mathrm{NS}}$ & $-1.18(0.09)$ & $-2.15(0.17)$ & $70.8^{* * *}$ & $-1.11(0.08)$ & $-2.11(0.17)$ & $69.2^{* * *}$ \\
\hline C12 index & $0.0^{\mathrm{NS}}$ & $-0.29(0.02)$ & $-0.55(0.05)$ & $51.5^{* * *}$ & $-0.29(0.03)$ & $-0.53(0.05)$ & $50.8^{* * *}$ \\
\hline C14 index & $0.0^{\mathrm{NS}}$ & $-1.34(0.08)$ & $-2.59(0.16)$ & $98.4^{* * *}$ & $-1.31(0.08)$ & $-2.59(0.16)$ & $97.0^{* * *}$ \\
\hline C16 index & $0.2^{\mathrm{NS}}$ & $0.47(0.04)$ & $0.98(0.08)$ & $56.7^{* * *}$ & $0.49(0.04)$ & $1.05(0.09)$ & $58.7^{* * *}$ \\
\hline C18 index & $0.1^{\mathrm{NS}}$ & $0.85(0.19)$ & $1.51(0.37)$ & $6.6^{* * *}$ & $0.75(0.20)$ & $1.47(0.39)$ & $7.0^{* * *}$ \\
\hline CLA index & $0.3^{\mathrm{NS}}$ & $1.29(0.20)$ & $2.43(0.40)$ & $14.3^{* * *}$ & $1.14(0.20)$ & $2.13(0.39)$ & $15.0^{* * *}$ \\
\hline
\end{tabular}

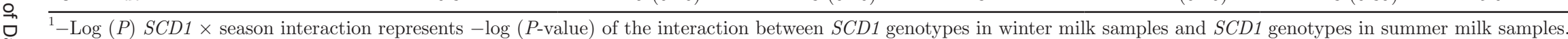

宸. $\quad$ Estimated contrast of VA - AA genotypes, where AA is set to zero, obtained using model 1 extended with $S C D 1$ A293V as a fixed genotype effect.

œ ${ }^{3}$ Estimated contrast of $\mathrm{VV}$ - AA genotypes, where AA is set to zero, obtained using model 1 extended with $S C D 1$ A293V as a fixed genotype effect.

$\stackrel{\frac{\Omega}{\Phi}}{~} \quad{ }^{4}$ Significance levels are represented by $-\log (P$-value) of the effects of $S C D 1$ A293V polymorphism in winter and summer milk samples, respectively. Nominal $P$-values are reported.

${ }_{\varnothing}^{5} \mathrm{CLA}=$ conjugated linoleic acid.

$\subseteq{ }^{6} \mathrm{UFA}=$ unsaturated FA.

๑ $\quad * * * P<0.001 ;{ }^{* *} P<0.01 ;{ }^{*} P \leq 0.05$. 


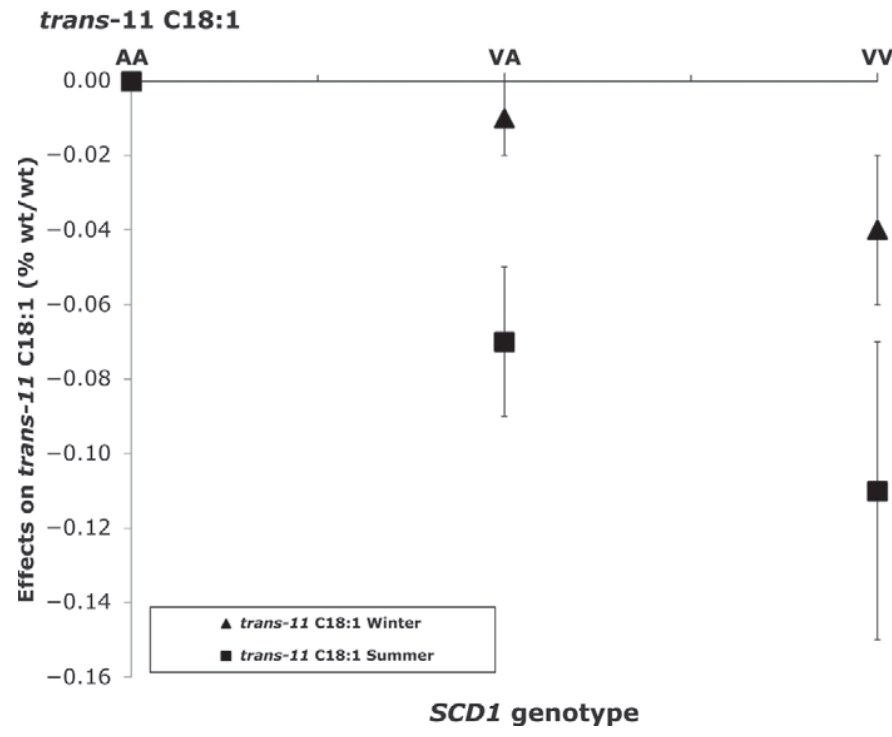

Figure 2. Estimated effects of stearoyl-CoA desaturase 1 (SCD1) A293V polymorphism in winter and summer samples represented by the contrasts of VV - AA and VA - AA genotypes, where AA is set to zero. These contrasts illustrate the significant $S C D 1 \mathrm{~A} 293 \mathrm{~V}$ by season interaction on trans-11 C18:1. Standard errors are shown as error bars.

are due to scaling rather than to reranking (Figures 1 and 2). High genetic correlations between milk fat composition in winter and summer as well as similar genotypic effects in winter and summer support the idea that mainly the same genes are involved in milk fat composition in winter and in summer.

DGAT1. The gene encoding acyl-CoA:diacylglycerol acyltransferase 1 is DGAT1 (EC 2.3.1.20) and the K232A polymorphism causes an amino acid change (lysine > alanine at position 232 of the protein), which might alter the activity or specificity of the enzyme, responsible for the fixation of FA to the third position of triacylglycerol (Cases et al., 1998; Palmquist, 2006; Yen et al., 2008). In our study, the DGAT1 232A allele was associated with a lower milk fat percentage, which agrees with previous research (e.g., Grisart et al., 2002; Winter et al., 2002; Thaller et al., 2003).

The DGAT1 enzyme shows a preference to esterify short-chain FA and UFA to the third position of a triacylglycerol (Kinsella, 1976; Morand et al., 1998; Mistry and Medrano, 2002). In winter, the DGAT1 232A allele was negatively associated with most FA with less than 18 carbons and was positively associated with all unsaturated C18. In summer milk, larger amounts of UFA were found compared with winter milk. This larger supply seems to increase the effect of the DGAT1 K232A polymorphism, especially for UFA for which it has preference, because the effects of DGAT1 232A allele on most unsaturated C18 and UFA were larger in summer compared with winter milk and resulted in $D G A T 1$ by season interaction.

$S C D 1$. The gene encoding stearoyl-CoA desaturase 1 is SCD1 (EC 1.14.19.1) and the A293V polymorphism causes an amino acid change (alanine $>$ valine at position 293 of the protein), which might affect the catalytic function of the enzyme, responsible for the insertion of a cis double bond between carbon 9 and 10 of a FA (Pereira et al., 2003). In the present study, SCD1 A293V polymorphism had no significant effect on fat percentage. This result is in line with Schennink et al. (2008).

Unsaturation indices have been suggested as indicators to indirectly measure the desaturation activity of the SCD1 enzyme (e.g., Peterson et al., 2002). In both winter and summer, high means for C18 and CLA unsaturation indices (Table 2) indicate that C18:0 and trans-11 C18:1 are unsaturated to a higher extent than C10:0, C12:0, C14:0, and C16:0. These results are in line with Enoch et al. (1976), who suggest that SCD1 has preferences in desaturating longer-chain FA. In addition, the SCD1 293V allele was positively associated with C16 to CLA indices compared with the SCD1 293A allele in both winter and summer (Table 6). These associations suggest that the SCD1 293V allele might have a higher affinity or specificity to desaturate longer-chain FA (e.g., C18:0 or trans-11 C18:1) than other available FA (e.g., C10:0 or C14:0).

\section{CONCLUSIONS}

Milk fat composition in winter and in summer can be largely considered as genetically the same trait, because of the very high genetic correlations found between winter and summer milk fat composition. Differences in milk fat composition between winter and summer can probably be attributed to differences in the diets of cows between the 2 seasons rather than to genetic differences. Effects of DGAT1 K232A and SCD1 A293V polymorphisms on fat composition are similar in winter and in summer milk. Significant DGAT1 and SCD1 by season interactions were found for some FA and these interactions seem to be due to scaling of the genotype effects.

\section{ACKNOWLEDGMENTS}

This study is part of the Dutch Milk Genomics Initiative, funded by Wageningen University (Wageningen, the Netherlands), the Dutch Dairy Association NZO (Zoetermeer, the Netherlands), Cooperative Cattle Improvement Organization CRV (Arnhem, the Netherlands), and the Dutch Technology Foundation STW (Utrecht, the Netherlands). The authors thank the 
owners of the herds for their help in collecting the data. The first author currently benefits from a joint grant from the European Commission and CRV, within the framework of the Erasmus-Mundus joint doctorate "EGS-ABG". In addition, the first author expresses her gratitude for having benefitted, at the beginning of this research, from academic and financial support of the Erasmus Mundus program "European Master in Animal Breeding and Genetics (EM-ABG)," and the Koepon Foundation (Feerwerd, the Netherlands).

\section{REFERENCES}

Agenäs, S., K. Holtenius, M. Griinari, and E. Burstedt. 2002. Effects of turnout to pasture and dietary fat supplementation on milk fat composition and Conjugated Linoleic Acid in dairy cows. Acta Agric. Scand. A Anim. Sci. 52:25-33.

Bauman, D. E., and J. M. Griinari. 2003. Nutritional regulation of milk fat synthesis. Annu. Rev. Nutr. 23:203-227.

Bernard, L., C. Leroux, and Y. Chilliard. 2008. Expression and nutritional regulation of lipogenic genes in the ruminant lactating mammary gland. Pages 67-108 in Bioactive Components of Milk. Vol. 606. Z. Bösze, ed. Springer, New York, NY.

Cases, S., S. J. Smith, Y.-W. Zheng, H. M. Myers, S. R. Lear, E. Sande, S. Novak, C. Collins, C. B. Welch, A. J. Lusis, S. K. Erickson, and R. V. Farese. 1998. Identification of a gene encoding an acyl CoA:diacylglycerol acyltransferase, a key enzyme in triacylglycerol synthesis. Proc. Natl. Acad. Sci. USA 95:13018-13023.

Chilliard, Y., A. Ferlay, and M. Doreau. 2001. Effect of different types of forages, animal fat or marine oils in cow's diet on milk fat secretion and composition, especially conjugated linoleic acid (CLA) and polyunsaturated fatty acids. Livest. Prod. Sci. 70:31-48.

Chilliard, Y., A. Ferlay, R. M. Mansbridge, and M. Doreau. 2000. Ruminant milk fat plasticity: Nutritional control of saturated, polyunsaturated, trans and conjugated fatty acids. Ann. Zootech. 49:181-205.

Chilliard, Y., F. Glasser, A. Ferlay, L. Bernard, J. Rouel, and M. Doreau. 2007. Diet, rumen biohydrogenation and nutritional quality of cow and goat milk fat. Eur. J. Lipid Sci. Technol. 109:828 855 .

Dewhurst, R. J., N. D. Scollan, S. J. Youell, J. K. S. Tweed, and M. O. Humphreys. 2001. Influence of species, cutting date and cutting interval on the fatty acid composition of grasses. Grass Forage Sci. 56:69-74.

Dewhurst, R. J., K. J. Shingfield, M. R. F. Lee, and N. D. Scollan. 2006. Increasing the concentrations of beneficial polyunsaturated fatty acids in milk produced by dairy cows in high-forage systems. Anim. Feed Sci. Technol. 131:168-206.

Enoch, H. G., A. Catalá, and P. Strittmatter. 1976. Mechanism of rat liver microsomal stearyl-CoA desaturase. Studies of the substrate specificity, enzyme-substrate interactions, and the function of lipid. J. Biol. Chem. 251:5095-5103.

Falconer, D. S., and T. F. C. Mackay. 1996. Correlated characters: Genotype-environment interaction. Pages 321-325 in Introduction to Quantitative Genetics. 4th ed. Longman Greens, Harlow, Essex, UK.

FAO (Food and Agriculture Organization of the United Nations). 2008. Fats and fatty acids in human nutrition: Report of an expert consultation. FAO Food and Nutrition Paper 91. FAO, Geneva, Switzerland.

German, J. B., and C. J. Dillard. 2006. Composition, structure and absorption of milk lipids: A source of energy, fat-soluble nutrients and bioactive molecules. Crit. Rev. Food Sci. Nutr. 46:57-92.

Gilmour, A. R., B. J. Gogel, B. R. Cullis, and R. Thompson. 2002. ASReml User Guide Release 2.0. VSN International Ltd., Hemel Hempstead, UK.
Grisart, B., W. Coppieters, F. Farnir, L. Karim, C. Ford, P. Berzi, N. Cambisano, M. Mni, S. Reid, P. Simon, R. Spelman, M. Georges, and R. Snell. 2002. Positional candidate cloning of a QTL in dairy cattle: Identification of a missense mutation in the bovine DGAT1 gene with major effect on milk yield and composition. Genome Res. 12:222-231.

Grummer, R. R. 1991. Effect of feed on the composition of milk fat. J. Dairy Sci. 74:3244-3257.

Harfoot, C. G., and G. P. Hazlewood. 1997. Lipid in the rumen. Pages 382-426 in Rumen Microbial Ecosystem. 2nd ed. P. N. Hobson and C. S. Stewart, ed. Blackie Academic \& Professional, London, UK.

Heck, J. M. L., H. J. F. van Valenberg, J. Dijkstra, and A. C. M. van Hooijdonk. 2009. Seasonal variation in the Dutch bovine raw milk composition. J. Dairy Sci. 92:4745-4755.

Heringstad, B., D. Gianola, Y. M. Chang, J. Ødegård, and G. Klemetsdal. 2006. Genetic associations between clinical mastitis and somatic cell score in early first-lactation cows. J. Dairy Sci. 89:2236-2244.

Jenkins, T. C., R. J. Wallace, P. J. Moate, and E. E. Mosley. 2008. Board-invited review: Recent advances in biohydrogenation of unsaturated fatty acids within the rumen microbial ecosystem. J. Anim. Sci. 86:397-412.

Karijord, Ø., N. Standal, and O. Syrstad. 1982. Sources of variation in composition of milk fat. Z. Tierzücht. Züchtungsbiol. 99:81-93.

Kelsey, J. A., B. A. Corl, R. J. Collier, and D. E. Bauman. 2003 The effect of breed, parity, and stage of lactation on conjugated linoleic acid (CLA) in milk fat from dairy cows. J. Dairy Sci. $86: 2588-2597$.

Khanal, R. C., T. R. Dhiman, and R. L. Boman. 2008. Changes in fatty acid composition of milk from lactating dairy cows during transition to and from pasture. Livest. Sci. 114:164-175.

Kinsella, J. E. 1976. Monoacyl-sn-glycerol 3-phosphate acyltransferase specificity in bovine mammary microsomes. Lipids 11:680-684.

Lock, A. L., and D. E. Bauman. 2004. Modifying milk fat composition of dairy cows to enhance fatty acids beneficial to human health. Lipids 39:1197-1206.

Mach, N., A. A. A. Jacobs, L. Kruijt, J. van Baal, and M. A. Smits. 2011. Alteration of gene expression in mammary gland tissue of dairy cows in response to dietary unsaturated fatty acids. Animal 5:1217-1230.

Mistry, D. H., and J. F. Medrano. 2002. Cloning and localization of the bovine and ovine lysophosphatidic acid acyltransferase (LPAAT) genes that codes for an enzyme involved in triglyceride biosynthesis. J. Dairy Sci. 85:28-35.

Moioli, B., G. Contarini, A. Avalli, G. Catillo, L. Orrù, G. De Matteis, G. Masoero, and F. Napolitano. 2007. Short communication: Effect of stearoyl-coenzyme A desaturase polymorphism on fatty acid composition of milk. J. Dairy Sci. 90:3553-3558.

Morand, L. Z., J. N. Morand, R. Matson, and J. B. German. 1998. Effect of insulin and prolactin on acyltransferase activities in MACT bovine mammary cells. J. Dairy Sci. 81:100-106.

Palmquist, D. L. 2006. Milk fat: Origin of fatty acids and influence of nutritional factors thereon. Pages 43-92 in Advanced Dairy Chemistry: Lipids. Vol. 2. P. F. Fox and P. L. H. McSweeney, ed. Springer, New York, USA.

Palmquist, D. L., A. D. Beaulieu, and D. M. Barbano. 1993. Feed and animal factors influencing milk fat composition. J. Dairy Sci. 76:1753-1771.

Pereira, S. L., A. E. Leonard, and P. Mukerji. 2003. Recent advances in the study of fatty acid desaturases from animals and lower eukaryotes. Prostaglandins Leukot. Essent. Fatty Acids 68:97-106.

Peterson, D. G., J. A. Kelsey, and D. E. Bauman. 2002. Analysis of variation in cis-9, trans-11 conjugated linoleic acid (CLA) in milk fat of dairy cows. J. Dairy Sci. 85:2164-2172.

Precht, J., and D. Molketin. 2000. Frequency distributions of conjugated linoleic acid and trans fatty acids in European milk fats. Milchwissenschaft 55:687-691.

Renner, E., and U. Kosmack. 1974. Genetische Aspekte zur Fettsaürenzusammensetzung des Milchfettes. Züchtungskunde 46:217-226.

Schennink, A., J. M. L. Heck, H. Bovenhuis, M. H. P. W. Visker, H. J. F. van Valenberg, and J. A. M. van Arendonk. 2008. Milk fatty 
acid unsaturation: Genetic parameters and effects of stearoyl-CoA desaturase $(S C D 1)$ and acyl CoA: diacylglycerol acyltransferase 1 (DGAT1). J. Dairy Sci. 91:2135-2143.

Schennink, A., W. M. Stoop, M. H. P. W. Visker, J. M. L. Heck, H Bovenhuis, J. J. van der Poel, H. J. F. van Valenberg, and J. A. M. van Arendonk. 2007. DGAT1 underlies large genetic variation in milk-fat composition of dairy cows. Anim. Genet. 38:467-473.

Soyeurt, H., P. Dardenne, F. Dehareng, C. Bastin, and N. Gengler. 2008. Genetic parameters of saturated and monounsaturated fatty acid content and the ratio of saturated to unsaturated fatty acids in bovine milk. J. Dairy Sci. 91:3611-3626.

Soyeurt, H., P. Dardenne, A. Gillon, C. Croquet, S. Vanderick, P. Mayeres, C. Bertozzi, and N. Gengler. 2006. Variation in fatty acid contents of milk and milk fat within and across breeds. J. Dairy Sci. 89:4858-4865.

Sterk, A.-R. 2011. Ruminant fatty acid metabolism. PhD Thesis. Wageningen University, Wageningen, the Netherlands.

Stoop, W. M., J. A. M. van Arendonk, J. M. L. Heck, H. J. F. van Valenberg, and H. Bovenhuis. 2008. Genetic parameters for major milk fatty acids and milk production traits of Dutch HolsteinFriesians. J. Dairy Sci. 91:385-394.
Thaller, G., W. Krämer, A. Winter, B. Kaupe, G. Erhardt, and R. Fries. 2003. Effects of DGAT1 variants on milk production traits in German cattle breeds. J. Anim. Sci. 81:1911-1918.

Thorsdottir, I., J. Hill, and A. Ramel. 2004. Short communication Seasonal variation in cis-9, trans-11 conjugated linoleic acid content in milk fat from Nordic countries. J. Dairy Sci. 87:2800-2802.

Wilmink, J. B. M. 1987. Adjustment of test-day milk, fat and protein yield for age, season and stage of lactation. Livest. Prod. Sci $16: 335-348$

Winter, A., W. Krämer, F. A. O. Werner, S. Kollers, S. Kata, G. Durstewitz, J. Buitkamp, J. E. Womack, G. Thaller, and R. Fries. 2002. Association of a lysine-232/alanine polymorphism in a bovine gene encoding acyl-CoA:diacylglycerol acyltransferase (DGAT1) with variation at a quantitative trait locus for milk fat content. Proc. Natl. Acad. Sci. USA 99:9300-9305.

Yen, C.-L. E., S. J. Stone, S. Koliwad, C. Harris, and R. V. Farese Jr. 2008. Thematic review series: Glycerolipids. DGAT enzymes and triacylglycerol biosynthesis. J. Lipid Res. 49:2283-2301. 